\title{
Smallholder Agriculture and Land Reform in South Africa
}

\section{Edward Lahiff and Ben Cousins}

\section{Introduction}

How can land reform contribute to a revitalisation of smallholder agriculture in Southern Africa? This question remains important despite negative perceptions of land reform as a result of the impact of Zimbabwe's "fast-track" resettlement programme on agricultural production. This article focuses mainly on South Africa, where a highly unequal distribution of land coexists with deep rural poverty, but dominant narratives of the efficiency of largescale agriculture exert a stranglehold on rural policy (cf Toulmin and Guèye, this IDS Bulletin for West Africa).

The end of apartheid found a high proportion of the South African population residing in rural or semi-rural areas, but functionally dependent on the urban-industrial economy. Access to land by black people was effectively limited to the 13 per cent of land that made up the former homelands, much of which was overcrowded and unsuited to agriculture. Agricultural activities tended to be on a small scale and made only a minor contribution to household livelihoods, considerably less than wage employment and welfare payments. Ten years on, poverty and unemployment are still heavily concentrated in the rural areas, particularly in the former homelands but also in the former white commercial farming areas. Agricultural land is concentrated in the hands of approximately 45,000 corporate and individual owners, who are overwhelmingly white.

Since 1994, economic policies adopted by the democratic government have done little to develop the smallholder sector, and may even have contributed to its long-run decline. The deregulation of commodity markets and the removal of most state support to the agricultural sector since 1990 have contributed to a climate that is exceptionally hostile to new entrants and to existing smallholders wishing to expand production. Meanwhile, the collapse of most state agricultural services in the former homelands since 1990 has further undermined existing producers. Market-based land reforms implemented by the democratic government have had a minimal impact on the racial distribution of agricultural land and have promoted new black entrants to the commercial farming sector at the expense of smallholders.

Nevertheless, land reform has the potential to underpin a revitalised system of smallholder production, in tandem with a transformation of the agricultural sector in ways that would promote economic development and reduce poverty in the rural areas (see Olukoshi, this IDS Bulletin). This would involve three key, interrelated elements: large-scale redistribution of land, enhanced state support to existing black smallholders and reform of agricultural markets

\section{Current status of smallholder agriculture}

Smallholder agriculture is found in a wide range of locations, including "deep rural" areas of the former homelands, in townships and cities, and on commercial farms, and consists mainly of production of staple foods for household consumption. Relatively few products find their way into local or other markets. Production may take place in gardens, demarcated fields or on open rangelands. It is highly differentiated by race, class and gender, with large numbers of very poor black women producing purely for household consumption and a small "élite", mainly men, producing on a much greater scale. Many smallholders would not consider themselves to be "farmers" in the conventional sense. Few records of production and trade are kept by either producers or external agencies, and the value and volume of

IDS Bulletin Vol 36 No 2 June 2005 @ Institute of Development Studies 
smallholder production that appears in the literature is probably only a fraction of the actual output.

Insofar as black people have access to agricultural land, therefore, it is still largely confined to the former homelands. As in the rest of the country, only a small proportion of this land is suitable for arable farming, with only a miniscule area under irrigation. Much of this land is severely overcrowded, which is why land redistribution is an essential precondition for improved levels of production. The literature suggests that access to arable land in the homelands is available to a relatively large proportion of households, perhaps as high as 50 per cent, but average holdings are extremely small, in the order of 0.5 to 1.5 ha per household. There is, however, considerable variation in plot sizes, with a substantial proportion of households cultivating less than 0.5 ha, and a small group cultivating plots greater than 5 ha (Lahiff 1997).

Livestock farming remains widespread, albeit with wide variations between households and regions. Between one-quarter and one-half of households own cattle, and the great majority of herds have fewer than ten animals. Only a tiny élite own herds of 50 cattle or more. Small stock - sheep and goats - are probably owned by slightly more households (Lahiff 1997). While livestock numbers per household are low, the overall contribution to the economy is significant. Bromberger and Antonie (1993: 409-49) show that, in 1990, 35 per cent of all cattle in South Africa were found in the homelands, along with 12 per cent of sheep and 60 per cent of goats. Although less important than cropping, livestock contribute to household livelihoods in a wide variety of ways, including food, draught power, bridewealth and savings, all of which are underestimated (or ignored) by conventional economic analyses.

Wages (migrant and non-migrant) are the most important source of income for households in the homelands. Pensions are the second most important source, contributing between about 10 per cent and 20 per cent of average income. Estimates of agricultural income, in terms of both cash sales and produce consumed directly, show the greatest variability, but most studies put it at between 10 per cent and 25 per cent of average household income (Lahiff 1997). Agriculture does provide an important supplement, especially those with little access to wage income and a vital safety net in times of crisis (Andrew et al. 2003).
Land-based activities - cropping, livestock and harvesting of wild resources - constitute an integral part of the livelihood strategies of the majority of households in rural South Africa, but not the most important part in most cases. The generally low contribution of smallholder agriculture to rural livelihoods can be attributed to a lack of resources - particularly land, equipment and working capital - a lack of support services (state and private), and a market structure that makes it difficult for smallholders to access the inputs they require and suitable outlets for their produce.

\section{Developing smallholder agriculture}

Over the years, a range of interventions have been made by the South African State and others to develop smallholder agriculture, with limited success. Most have reached only a small élite, and many have proved unsustainable in the absence of major state support. Since 1994, development programmes such as the Integrated Sustainable Rural Development Programme have tended to downplay land-based livelihoods in general, and smallholder agriculture in particular. Limited support is offered by provincial Departments of Agriculture, but this reaches only a minority of existing smallholders and new land reform beneficiaries. In 2004, a new but relatively small 'Comprehensive Agricultural Support Programme' was announced and implementation is still at an early stage.

Experience from Zimbabwe indicates the dramatic expansion of smallholder agriculture that is possible under favourable circumstances. Prior to independence in 1980, black smallholders in Zimbabwe faced many of the constraints faced by South African producers today, most notably a market and policy structure that strongly favoured large-scale commercial agriculture, and was characterised by low productivity and slow growth. While planting two-thirds of the country's maize area, Zimbabwean smallholders harvested only onequarter of the total maize crop, and accounted for less than 5 per cent of the total maize delivered to national markets (Rohrbach 1988). Smallholders made up 95 per cent of farmers, but earned less than 10 per cent of agricultural income derived from crop and livestock sales through official channels. During the six years from 1979 to 1985 , the smallholder maize sub-sector expanded rapidly. Maize production more than tripled as areas planted 
increased by 90 per cent and yields roughly doubled. Sixty per cent of the production gains were delivered to national markets. As a result, the smallholder contribution to the Grain Marketing Board intake rose to over one-third of total maize deliveries.

Rohrbach (1988: 323) attributes this dramatic increase to a number of factors: the ending of the liberation war, the expansion of market infrastructure in communal areas, the availability of improved technology such as hybrid seeds and fertiliser, a reorientation of agricultural research and extension services away from the large-scale commercial sector, the establishment of a smallholder credit programme through the Agricultural Finance Corporation and increases in the real producer price of maize relative to inputs. While this package of reforms may not be replicable in other contexts, it does point to the potential of what Rohrbach describes as the complementary impact of a combined set of agricultural interventions'.

\section{Post-apartheid land reform}

South African land reform has not, to date, managed to transform the pattern of landholding in the country, or to impact significantly on rural livelihoods (Hall et al. 2003). By February 2004, only the equivalent of 2.9 per cent of total agricultural land (excluding the former homelands), benefiting less than 200,000 households, had been transferred.

Since 1999, there has been a policy shift away from providing land for the rural poor and landless for subsistence purposes, in favour of creating a new class of black commercial farmers on substantial holdings. Programmes specifically aimed at the poor have either been severely curtailed, as in the case of municipal commonage, or have failed to materialise, as in the case of a promised "food safetynet". Targets for the inclusion of marginalised groups such as women, youth and the disabled have been widely ignored. At the same time, support for "emerging" farmers with their own resources and access to credit has come to dominate the redistribution programme, and is actively promoted by the government Departments of Land and Agriculture and the state-owned Land Bank.

The general neglect of post-transfer support, and the failure to integrate land reform with a wider programme of rural development, has severely limited its contribution to livelihoods and to the revival of the rural economy. Redistributing land and rights in land cannot, by itself, achieve the objectives of alleviating poverty, promoting equality and contributing to economic growth. The implementation of a comprehensive agrarian reform that transforms the commercial agricultural sector, addresses the dualism of freehold and communal areas and provides livelihood opportunities for the mass of the rural poor and landless, remains a major challenge for the country.

\section{A new policy framework is needed}

Experience from Zimbabwe in the 1980s and other developing countries suggests that a more inclusive model of agriculture can have multiple benefits through greater absorption of labour, better distribution of income and better household nutrition, without necessarily compromising productivity. To achieve this, however, will require a major shift by the state and the private sector, and the commitment of substantial resources over a lengthy period.

The expansion of smallholder agriculture in South Africa will require reforms in three main areas.

1. Redistribution of land and other assets from the largescale to the smallholder sector. A substantial transfer of agricultural land - in the range of 30-50 per cent of the total - will require systematic acquisition and sub-division of appropriate farmland, in ways that have not been possible to date under the market-based system. Beneficiaries should include a wide range of social groups, including residents of the former homelands, commercial farms and urban areas, and be free to use land in a variety of ways, from small food gardens to substantial commercial units.

2. Reform of agricultural markets. Upstream and downstream agricultural markets in South Africa today are characterised by monopolies and lack of regulation, and largely serve the needs of largescale commercial producers. Restructuring of markets will be required in order to create opportunities for new entrants operating on a smaller scale and serving local markets, and to offer a degree of price stability for producers. Much of this can be achieved through regulation of market agents (e.g. unbundling of the big buyers and suppliers), but a limited degree of price controls and import restrictions may also be required, especially with regard to staple food crops. 
3. Support to existing and new smallholders. Smallholders, whether in the former homelands or on new land reform projects, require a range of support services both to expand production and to compete with large commercial producers. At the farm level, this include agricultural extension and veterinary services, research, mechanical services, credit facilities, transport services, development of irrigation and other infrastructure, training and market information, all specifically targeted to the needs of smallholders. At a wider level, it includes upgrading of roads and bridges in rural areas, construction of market places and storage and processing facilities, such as mills and abattoirs, and support for local providers of agricultural services. Institutional support will also be required to build dynamic farmers' unions and cooperatives and to expand opportunities for farmer education.

\section{Area-based land and agrarian reform}

A proactive state can make use of market mechanisms to target land reform in regions of emerging opportunity and high demand. If government sets out to proactively match supply and demand in these regions, then large blocks could be acquired at reasonable cost. Infrastructure and support services could be provided to land reform projects in a much more cost-effective manner than is possible within the current patchwork pattern of land acquisition. The essential components of an area-based approach include:

- Zones of both need and opportunity for land and agrarian reform are carefully selected and designated

- Government provides funds for and facilitates a transparent process of land identification and acquisition by groups and individuals

- Key decisions in relation to land use, systems of production and land tenure are made by the participants themselves, not by officials or consultants

- A range of scales of production and degrees of "commercialisation" on the acquired land should be allowed, and variable definitions and interpretations of the "viability" of production should be accepted

- Government undertakes district-wide planning for infrastructure and service provision, especially in relation to post-transfer support, including marketing of produce

- Planning for land and agrarian reform is made central to the processes leading to the formulation of Integrated Development Plans by local government bodies

- State land is contributed to the process where appropriate.

A range of priorities can be identified, based on high demand for land and opportunities for areabased land reform. These include the following:

- Commercial farming areas adjacent to communal areas. Research has revealed that many commercial farmers in these zones are eager to sell, and at fairly low prices (Aliber and Mokoena 2002). Often their farms have good agricultural potential. However, there are large numbers of poor people without access to sufficient (or, in some cases, any) arable or grazing land.

- Areas in which there are large rural populations, small towns with growing economies and adjacent high potential agricultural land, enhancing prospects for combining land-based and urban livelihoods, and for agro-processing enterprises and employment. Hart (1996) suggests such a scenario in the KwaZulu-Natal Midlands.

- Peri-urban areas with good agricultural potential, and sometimes with common land owned by local municipalities (e.g. in the Free State, Eastern Cape and Northern Cape). Peri-urban areas often have potential for intensive forms of small-scale production (market gardening, dairying, poultry) for local and more distant markets.

- Districts with high proportions of rural restitution claims (e.g. districts in Limpopo Province). Here, restitution and redistribution can become highly complementary programmes of agrarian transformation.

- Areas with the potential for expanded production by smallholders of high-value cash crops (sugar, cotton, subtropical fruit and specialist vegetables) and associated agro-processing. One possibility to explore in these areas would be the use of redistributed large-scale farming and processing concerns as core service nodes for an expanding smallholder sector.

Ten years of experience in South Africa clearly demonstrate that market-based land and agrarian 
reforms, in the context of neoliberal globalisation, are unlikely to achieve either a substantial redistribution of assets to the poor or a revitalisation of the rural economy. Faced with rural poverty on a massive scale, and little prospect of creating

\section{References}

Aliber, M. and Mokoena, R., 2002, 'The interaction between the land redistribution programme and the land market in South Africa: a perspective on the willing-buyer/willing-seller approach', Land Reform and Agrarian Change in Southern Africa Occasional Paper 21, Cape Town: Programme for Land and Agrarian Studies, University of the Western Cape

Andrew, M., Ainslie, A. and Shackleton, C., 2003, 'Land use and livelihoods', Evaluating Land and Agrarian Reform in South Africa 8, Cape Town: Programme for Land and Agrarian Studies, University of the Western Cape

Bromberger, N. and Antonie, F., 1993, 'Black small farmers in the homelands: economic prospects and policies', in M. Lipton and C. Simkins (eds), State and Market in Post Apartheid South Africa, Oxford: Westview Press: 409-49 employment for growing numbers of jobless within the urban economy, it is imperative to explore new models of smallholder development that will address the needs of the most vulnerable and marginalised groups.

Hall, R., Jacobs, P. and Lahiff, E., 2003. 'Final report', Evaluating Land and Agrarian Reform in South Africa 10, Cape Town: Programme for Land and Agrarian Studies, University of the Western Cape Hart, G., 1996, 'The agrarian question and industrial dispersal in South Africa: agro-industrial linkages through Asian lenses', in H. Bernstein (ed.), The Agrarian Question in South Africa, London: Frank Cass

Lahiff, E., 1997, An Apartheid Oasis: Agriculture and Rural Livelihoods in Venda, London: Frank Cass

Rohrbach, D., 1988, 'The growth of smallholder maize production in Zimbabwe (1979-1985): implications for food security', in M. Rukini and R. Bernstein (eds), Southern Africa: Food Security Policy Options, Harare: University of Zimbabwe/ Michigan State University Food Research Project, Department of Agricultural Economics and Extension 